\title{
PENGEMBANGAN POTENSI EKOWISATA DI DESA LIANG NDARA KABUPATEN MANGGARAI BARAT
}

Aurilia Hansni Yanita Ada a, 1, I Nyoman Sukma Arida a, 2

1aurelia.ada80@yahoo.com, 22sukma.arida@gmail.com

a Program Studi S1 Destinasi Pariwisata,Fakultas Pariwisata,Universitas Udayana, Jl. Dr. R. Goris, Denpasar, Bali 80232 Indonesia

ABSTRACT

Liang Ndara Village is one of the villages in West Manggarai Regency, which has ecotourism potential. Yet, based on the observation, the development of ecotourism potential is not maximize yet, so base on the case the observation was doing in order to know the potentials and the attraction of ecotourism, knowing the ecotourism practice and its similarity with ecotourism principles and to decide what action going to take in develop the ecotourism potential in Liang Ndara village with the research method of qualitative. The data collecting by observation, deeper interview, library study and the informant technique which is used is purposive sampling, that is the researcher deciding the informant base on the research purpose.

The output of the research shows that the potential and the attraction of the ecotourism in Liang Ndara village is Mbeliling Mountain Liang Kantor Waterfall, Cunca rami Waterfall, Liang Niki cave, Puncak Melo, attraction and culture, Compang kafir stone, logam Talang, weaving, Arak or local wine filtration and ricefield culturation. The practice of ecotourism in Liang Ndara village is not the same as the principles of ecotourism. There are eight criteria of ecotourism, which is not fulfilled yet. The ideal effort of ecotourism development is by fulfilling some criteria that is not fulfilled yet.

Keywords: ecotourism, potential, development

\section{PENDAHULUAN}

Desa Liang Ndara merupakan salah satu desa yang terletak di Kabupaten Manggarai Barat, Provinsi Nusa Tenggara Timur, yang memiliki potensi wisata alam dan budaya yang beragam. Melihat potensi wisata alam dan budaya yang ada di Desa Liang Ndara masih sangat alami, maka konsep wisata yang sangat cocok adalah ekowisata. Dimana dalam pengembangan pariwisata dengan konsep ekowisata dapat melestarikan kekayaan alam dan budaya untuk tetap berkelanjutan, selain itu dapat memberdayakan masyarakat lokal semaksimal mungkin, karena seluruh aset produksi yang digunakan merupakan milik masyarakat lokal (Suryawan, 2014). Selain itu letaknya sangat strategis yaitu berada di jalur utama Jalan Raya Trans Flores dan letaknya tidak jauh dari Kota Labuan Bajo (Ibukota Kabupaten Manggarai Barat) yaitu sekitar tiga puluh menit dengan menggunakan kendaraan roda dua/empat.

Untuk potensi wisata belum dimanfaatkan secara optimal. Desa Liang Ndara sudah memiliki suatu paket wisata tersendiri yaitu wisata budaya, karena di Desa Liang Ndara memiliki empat sanggar budaya yang mementaskan budaya lokal, yaitu budaya Manggarai, sehingga kebanyakan wisatawan yang berkunjung hanya sebatas datang untuk menyaksikan atraksi budaya. Padahal masih banyak potensi wisata lainnya yang perlu dikunjungi.

Sejumlah potensi yang dikembangkan dan upaya pengembangan yang dilakukan oleh lembaga swasta dan masyarakat, ternyata belum maksimal, masih banyak kendala yang dihadapi. Hal ini dikarenakan keterbatasan sumber daya manusia, kurangnya keterlibatan pemerintah dan masyarakat. Sehingga penitlitian ini penting dilakukan untuk mengetahui potensi dan atraksi ekowisata, praktek ekowisata dan upaya yang dapat dilakukan dalam pengembangan potensi ekowisata di Desa Liang Ndara.

\section{KEPUSTAKAAN}

2.1. Ekowisata

Ekowisata merupakan konsep pariwisata yang mencerminkan wawasan lingkungan, keseimbangan dan kelestarian lingkungan (Damanik dan Weber, 2006). Menurut TIES (The International Ecotourism Society), (dalam Arida, 2009) ekowisata merupakan perjalanan wisata alam yang bertanggung jawab dengan cara melakukan konservasi lingkungan dan alam serta meningkatkan kesejahteraan masyarakat lokal (TIES, 2000).

\subsection{Konsep Prinsip-Prinsip Ekowisata}

Adapun prinsip dan kriteria ekowisata yang dihasilkan dalam konverensi ekowisata di Bali 
oleh Kementrian Lingkungan Hidup pada tanggal

3-5 September 2002 (dalam Arida, 2009), yaitu:

1. Adanya kepedulian, komitmen dan tanggung jawab terhadap konservasi alam dan budaya.

2. Memberikan peluang kepada wisatawan untuk menikmati dan meningkatkan kecintaannya terhadap alam dan budaya.

3. Memberdayakan dan mengoptimalkan partisipasi serta sekaligus memberikan kontribusi secara kontinyu terhadap masyarakat setempat.

4. Peka dan menghormati nilai-nilai sosial budaya dan tradisi keagamaan masyarakat setempat.

5. Mentaati peraturan perundang-undangan yang berlaku.

6. Pengembangannya harus didasarkan atas musyawarah dan dengan persetujuan masyarakat setempat.

7. Secara konsisten memberikan kepuasan kepada konsumen.

8. Dipasarkan dan dipromosikan dengan jujur dan akurat sehingga sesuai dengan harapan dan kenyataan.

9. Sistem pengelolaan yang serasi dan seimbang sesuai dengan konsep Tri Hita Karana.

\subsection{Konsep Potensi Wisata}

Secara umum potensi wisata dapat dijabarkan sebagai berikut:

1. Potensi alam merupakan potensi yang ada di masyarakat seperti potensi fisik dan geografis.

2. Potensi budaya merupakan potensi yang tumbuh dan berkembang di masyarakat, yakni kehidupan sosial budaya masyarakat, kesenian, adat istiadat, mata pencaharian dan lainnya (Pendit, 1999).

\section{METODOLOGI PENELITIAN}

Metode pengumpulan data yang digunakan Penelitian ini dilakukan di Desa Liang Ndara, Kabupaten Manggarai Barat, Provinsi Nusa Tenggara Timur. Alasan Desa Liang Ndara dipilih sebagai lokasi penelitian karena memiliki potensi ekowisata yang bisa dikembangkan menjadi atraksi ekowisata. Dalam membatasi dan mempertegas penelitian yang akan dilakukan, maka ruang lingkup penelitian ini adalah; potensi dan atraksi ekowisata , yaitu potensi alamiah dan potensi budaya, praktek ekowisata dilihat dari prinsip-prinsip ekowisata yang dihasilkan dalam konverensi ekowisata se-Bali dan upaya pengembangan potensi ekowisata dengan memenuhi kriteria dari prinsip ekowisata yang belum terpenuhi. Teknik penentuan informan yang digunakan adalah purposive sampling, yaitu peneliti menentukan informan didasarkan atas maksud dan tujuan penelitian (Arikunto, 2013). Tujuan penelitian ini adalah untuk mengetahui potensi ekowisata, praktek ekowisata dan pengembangan potensi ekowisata di Desa Liang Ndara, maka informan yang dipilih adalah Kepala Desa, masyarakat lokal, tokoh adat, tokoh agama, lembaga swadaya masyarakat dan kelompok sanggar budaya.

Teknik pengumpulan data yang digunakan dalam penelitian ini adalah; Observasi dengan mengunjungi lokasi penelitian dengan tujuan untuk mengetahui kondisi fisik Desa Liang Ndara, Proses wawancara yang dilakukan guna mendapatkan informasi dan data tentang potensi dan atraksi ekowisata, praktek ekowisata dan upaya yang dapat dilakukan dalam mengembangkan potensi ekowisata. Studi Kepustakaan dilakukan untuk melengkapi hasil penelitian berupa data yang diambil dari Kantor Desa Liang Ndara, website dan penelusuran dokumen tentang Desa Liang Ndara.

\section{HASIL DAN PEMBAHASAN}

4.1. Gambaran Umum Desa Liang Ndara.

Desa Liang Ndara memiliki luas 618,5 ha dengan ketinggian 500 mdl. Secara administratif Desa Liang Ndara dibagi dalam tiga kampung, yaitu; Kampung Melo, Kampung Cecer dan Kampung Mamis. Jumlah penduduk di Desa Liang Ndara sebanyak 882 orang. Di Desa Liang Ndara memiliki fasilitas penunjang wisata, yaitu; penginapan, kios cendramata, papan informasi wisata, tempat sampah dan toilet. Daya tarik wisata di Desa Liang Ndara dikelola oleh LSM Burung Indonesia, LSM INDECON (Indonesian Ecotourism Network), Sanggar Compang To'e, Sanggar Nipu Tai, Sanggar Riang Tanah Tiwa dan Sanggar Lembu Nai.

\subsection{Potensi dan Atraksi Ekowisata}

1. Potensi dan Atraksi Ekowisata Alamiah.

Potensi dan atraksi ekowisata alam di Desa Liang Ndara adalah; Gunung Mbeliling (atraksi wisata; traking, pengamatan burung, berkemah, mengenal berbagai jenis tumbuhan, menikmati suasana alam, menikmati pemandangan, menikmati sunset dan sunrise), Air Terjun Liang Kantor (atraksi 
wisata; mandi/berenang dan menikmati alam di sekitar air terjun), Air Terjun Cunca Rami (atraksi wisata; berenang dan menikmati suasana alam), Gua Liang Niki (atraksi wisata; treking, menyaksikan aktifitas kelalawar dan menikmati alam), Puncak Melo (atraksi wisata; menyaksikan atraksi wisata budaya, menikmati pemandangan dan sunset.

2. Potensi dan Atraksi Ekowisata Budaya

Di Desa Liang Ndara terdapat banyak kebudayaan yang diwariskan secara turun temurun, yaitu: Sanggar Budaya (Atraksi wisata; Tarian Caci, Tarian Rangkuk Alu, Tarian Ndundung Ndake, penyambutan wisatawan secara adat, menikmati kuliner lokal, belajar menenun dan menganyam serta membeli cendramata hasil kerajinan masyarakat lokal), kegiatan menenun dan menganyam (atraksi wisata; belajar menenun dan menganyam), penyulingan sopi (atraksi wisata; belajar proses penyulingan sopi), membajak sawah (atraksi wisata; belajar membajak sawah dengan menggunakan kerbau), Logam Talang dan Batu Compang Kafir belum memiliki atraksi wisata.

\subsection{Praktek Ekowisata}

Sebelum merumuskan upaya pengembangan potensi ekowisata, maka harus diketahui dulu praktek ekowisata berdasarkan prinsip-prinsip ekowisata yang dihasilkan dalam penyelenggaraan konverensi ekowisata di Bali, yaitu:

1. Keseimbangan pemanfaatan lahan.

Luas wilayah di Desa Liang Ndara adalah 618,5 ha, dan lahan yang ada di Desa Liang Ndara digunakan untuk permukiman warga $40 \%$, hutan $30 \%$, dan sisanya $30 \%$ untuk lahan pertanian dan perkebunan (profil Desa Liang Ndara, 2016).

2. Penggunaan teknologi ramah lingkungan.

Penginapan yang disediakan untuk wisatawan masih menggunakan rumah masyarakat lokal yang masih tradisional dan belum menggunakan $A C$ ataupun kolam renang.

3. Pemanfaatan areal warisan budaya sebagai objek ekowisata disesuaikan dengan daya dukung.

Saat ini keberadaan warisan budaya seperti; Batu Compang Kafir, Logam Talang dan atraksi seni budaya masih terjaga. Jumlah kunjungan wisatawan meningkat setiap tahun tetapi belum ada aturan mengenai batasan jumlah kunjungan wisatwan. Sehingga kedepannya akan memberikan dampak yang negatif bagi keberadaan warisan budaya tersebut.

4. Melestarikan keanekaragaman hayati dan cagar budaya.

Kegiatan yang dilakukan dalam melestarikan keanekaragaman hayati adalah melakukan konservasi terhadap lingkungan dan semua satwa liar. Keberadaan cagar budaya masih tetap terjaga hingga sekarang.

5. Memperhatikan keberadaan endimisitas.

Endemisitas di Desa Liang Ndara adalah tiga jenis burung endemik Flores, yaitu Serindit Flores, Kehicap Flores dan Gagak Flores. LSM Burung Indonesia melakukan upaya dalam menjaga kelestarian burung endemik Flores dan jenis burung lainnya, yaitu dengan melakukan konservasi.

6. Menyediakan pramuwisata profesional dan berlisensi.

Belum ada yang bisa memandu dan melayani wisatawan dengan profesional. Hal ini dikarenakan minimnya kemampuan bahasa Inggris dan pelayanan dari masyarakat lokal.

7. Menyediakan fasilitas pendukung dan informasi yang memadai terkait objek ekowisata.

Masih ada beberapa fasilitas yang belum tersedia, seperti; restoran/warung makan, peralatan pengamatan burung, perlengkapan berkemah, juga belum tersedianya pusat informasi wisata dan plang/papan penunjuk objek wisata.

8. Memprioritaskan tenaga kerja lokal sesuai dengan keahlian.

Dengan adanya empat sanggar budaya yang ada di Desa Liang Ndara memberikan peluang kepada masyarakat lokal untuk berpartisipasi dalam kegiatan yang ada di kelompok sanggar budaya tersebut.

9. Mengutamakan pemanfaatan produk lokal untuk operasional objek ekowisata.

Hasil kerajinan lokal masyarakat di Desa Liang Ndara sudah dimanfaatkan sebagai cendramata. Selain itu bangunan yang terdapat di empat sanggar budaya terbuat dari kayu/bambu dan beratap ijuk, yang 
berasal dari perkebunan masyarakat Liang Ndara.

10. Melibatkan lembaga adat setempat.

Berbagai kegiatan dan diskusi yang dilakukan melibatkan pihak-pihak pengelola, masyarakat lokal dan lembaga adat.

11. Pembangunan dan operasional disesuaikan dengan tata krama, norma dan kearifan lokal setempat.

Pembangunan fasilitas kepariwisataan maupun aktifitas wisata yang berlangsung sama sekali tidak bertentangan dengan tata krama, norma dan kearifan lokal.

12. Keberadaan dan kegiatan ekowisata tidak mengganggu aktifitas keagamaan masyarakat setempat.

Masyarakat di Desa Liang Ndara menganut dua agama/kepercayaan, yaitu Katolik dan Islam. Selama ini aktifitas kepariwisataan tidak mengganggu aktifitas keagamaan masyarakat setempat.

13. Mentaati undang-undang dan perangkat peraturan lainnya.

Saat ini pemerintah Kabupaten Manggarai Barat belum membuat peraturan mengenai arah kebijakan pengembangan ekowisata di Kabupaten Manggarai Barat.

14. Mentaati peraturan desa setempat.

Belum ada peraturan yang terkait dengan kebijakan pengembangan ekowisata, sehingga banyak lahan pertanian masyarakat lokal yang sudah dijual kepada investor.

15. Pembangunan perlu mendapat persetujuan masyarakat dan lembaga adat setempat.

Awal pengembangan Desa Liang Ndara sebagai daya tarik ekowisata telah mendapat persetujuan masyarakat dan lembaga adat setempat dengan melakukan musyawarah dan diskusi.

16. Menjalin komunikasi dan koordinasi dengan masyarakat dan lembaga adat setempat dalam pengembangan objek.

Dalam pengembangan objek wisata di Desa Liang Ndara selalu melakukan komunikasi dan koordinasi dengan masyarakat dan lembaga adat melalui musyawarah dan diskusi.

17. Menyediakan fasilitas dan memberikan pelayanan prima dan memuaskan kepada konsumen.

Fasilitas wisata yang terdapat di Desa Liang Ndara masih sangat terbatas. Ada beberapa fasilitas wisata yang belum ada, seperti; warung makan, pusat informasi wisata, plang penunjuk objek wisata, alat pengamat burung, seperti teropong, dan perlengkapan berkemah, juga belum adanya karcis masuk di setiap objek wisata, sehingga konsumen belum mendapatkan pelayanan prima dan memuaskan.

18. Menyediakan media untuk memperoleh masukan dan pesan/kesan dari konsumen.

Di setiap daya tarik wisata alam dan budaya belum menyediakan media umpan balik, karena pengembangan daya tarik wisata tersebut belum maksimal, seperti belum adanya data kunjungan wisatawan.

19. Materi pemasaran harus akurat, jelas dan berkualitas.

Desa Liang Ndara belum memiliki website atau blog untuk melakukan promosi daya tarik ekowisata. Pemasaran atau promosi yang dilakukan selama ini dibantu oleh berbagi pihak. Pihak pengelola ekowisata Liang Ndara melakukan kerjasama dengan travel agent, hotel, kapal pesiar, restoran dan lainnya.

20. Materi pemasaran yang jujur dan harus sesuai dengan kenyataan.

Wisatawan yang berkunjung ke Desa Liang Ndara tidak pernah kecewa dan mereka sangat puas karena promosi yang dilakukan sesuai dengan kenyataan yang ada di Desa Liang Ndara.

21. Keselarasan hubungan antara manusia dengan Tuhan.

Masyarakat di Desa Liang Ndara sangat religius. Mereka selalu rutin melakukan ibadah sesuai dengan kepercayaan masing-masing dan kehidupan antara umat beragama sangat harmonis.

22. Keselarasan hubungan antara manusia dengan manusia.

Hubungan antara masyarakat di Desa Liang Ndara sangat harmonis. Hal ini tercermin dari rendahnya konflik dan tingkat kejahatan yang terjadi di masyarakat.

23. Keselarasan hubungan antara manusia dengan lingkungan.

Masyarakat di Desa Liang Ndara sangat peduli dengan lingkungan dan alam. Hal ini dibuktikan dengan tindakan mereka; menanam pohon, tidak menebang hutan dan tidak mencemari lingkungan dan alam. 
Tabel 4.3

Penyelenggaraan dan kegiatan ekowisata di Desa Liang Ndara yang belum terpenuhi berdasarkan prinsip-prinsip ekowisata

\begin{tabular}{|c|c|c|}
\hline No & $\begin{array}{l}\text { Kriteria dari prinsip- } \\
\text { prinsip ekowisata }\end{array}$ & Keterangan \\
\hline 1 & $\begin{array}{l}\text { Pemanfaatan areal warisan } \\
\text { budaya sebagai objek } \\
\text { ekowisata disesuaikan } \\
\text { dengan daya dukung. }\end{array}$ & $\begin{array}{l}\text { Kunjungan wisatawan semakin meningkat, tetapi belum ada } \\
\text { peraturan mengenai batasan jumlah kunjungan. Sehingga akan } \\
\text { memberikan dampak negatif bagi keberadaan warisan budaya. }\end{array}$ \\
\hline 2 & $\begin{array}{l}\text { Menyediakan pramuwisata } \\
\text { yang profesional dan } \\
\text { berlisensi. }\end{array}$ & Belum tersedianya pramuwisata yang profesional dan berlisensi. \\
\hline 3 & $\begin{array}{l}\text { Menyediakan fasilitas } \\
\text { pendukung dan informasi } \\
\text { yang memadai terkait objek } \\
\text { ekowisata }\end{array}$ & $\begin{array}{l}\text { Ada beberapa fasilitas yang belum tersedia; restoran/warung makan, } \\
\text { peralatan pengamatan burung, perlengkapan berkemah, pusat } \\
\text { informasi wisata dan plang penunjuk objek wisata. }\end{array}$ \\
\hline 4 & $\begin{array}{l}\text { Mentaati undang-undang } \\
\text { dan perangkat peraturan } \\
\text { lainnya. }\end{array}$ & $\begin{array}{l}\text { Pemerintah Kabupaten Manggarai Barat belum membuat peraturan } \\
\text { mengenai arah kebijakan pengembangan ekowisata. }\end{array}$ \\
\hline 5 & $\begin{array}{l}\text { Mentaati peraturan desa } \\
\text { setempat. }\end{array}$ & $\begin{array}{l}\text { Saat ini banyak lahan masyarakat lokal yang sudah dijual kepada } \\
\text { investor. Hal ini dikarenakan belum adanya peraturan terkait } \\
\text { pengembangan ekowisata di Desa Liang Ndara. }\end{array}$ \\
\hline 6 & $\begin{array}{l}\text { Menyediakan fasilitas dan } \\
\text { memberikan pelayanan } \\
\text { prima dan memuaskan } \\
\text { kepada konsumen }\end{array}$ & $\begin{array}{l}\text { Fasilitas wisata masih sangat terbatas juga belum adanya karcis } \\
\text { masuk di setiap objek wisata, sehingga wisatawan belum } \\
\text { mendapatkan pelayanan prima dan memuaskan. }\end{array}$ \\
\hline 7 & $\begin{array}{l}\text { Menyediakan media untuk } \\
\text { memperoleh umpan balik } \\
\text { dari konsumen. }\end{array}$ & $\begin{array}{l}\text { Pengembangan untuk setiap daya tarik wisata belum maksimal, } \\
\text { seperti belum adanya data kunjungan wisatawan. Sehingga tidak } \\
\text { mendapatkan umpan balik terkait masukan dan pesan/kesan dari } \\
\text { wisatawan terhadap objek wisata yang dikunjungi. }\end{array}$ \\
\hline 8 & $\begin{array}{l}\text { Materi pemasaran harus } \\
\text { jelas, akurat dan berkualitas. }\end{array}$ & $\begin{array}{l}\text { Belum memiliki website/blog untuk melakukan promosi daya tarik } \\
\text { ekowisata. Sehingga materi yang dipasarkan belum jelas, akurat dan } \\
\text { berkualitas. }\end{array}$ \\
\hline
\end{tabular}

Sumber: Data Olahan Penulis (2016)

\subsection{Upaya Pengembangan Potensi Ekowisata.}

Upaya pengembangan yang ideal adalah dengan memenuhi kriteria dari prinsip ekowisata yang belum terpenuhi dilihat dari praktek ekowisata di Desa Liang Ndara, yaitu:

1. Membuat atauran mengenai batasan jumlah pengunjung agar sesuai dengan daya tampung dan daya dukung kawasan.

2. Melakukan pola pendampingan masyarakat yang sifatnya berkelanjutan. Terutama dalam hal kegiatan pelatihan pemandu dan pelatihan bahasa Inggris.

3. Pihak pengelola dan pemerintah diharapkan memperhatikan dan menyediakan fasilitas penunjang yang belum tersedia.

4. Pemerintah Kabupaten Manggarai Barat harus membuat kebijakan pengembangan ekowisata.
5. Lembaga desa, lembaga adat dan masyarakat lokal harus membuat peraturan untuk melarang masyarakat menjual lahan pertanian kepada investor.

6. Menyediakan fasilitas wisata yang belum tersedia dan memberikan pelayanan yang prima dan memuaskan kepada konsumen dengan meningkatkan upaya pengembangan di setiap objek wisata terkait karcis masuk.

7. Perlu ditingkatkan kembali pengembangan untuk setiap daya tarik ekowisata terkait data pengunjung agar dapat memperoleh masukan serta pesan dan kesan dari wisatawan saat mengunjungi objek wisata.

8. Membuat website/blog agar dapat mempromosikan potensi ekowisata dengan materi yang jelas, akurat dan berkualitas. 


\section{SIMPULAN DAN SARAN}

\subsection{Simpulan}

Potensi ekowisata di Desa Liang Ndara, yaitu potensi alam dan budaya dan dari potensi ekowisata tersebut terdapat berbagai atraksi wisata yang dilakukan wisatwan. Praktek ekowisata di Desa Liang Ndara belum sesuai dengan prinsip-prinsip ekowisata. Masih ada 8 kriteria dari prinsip ekowisata yang belum terpenuhi. Upaya pengembangan yang dapat dilakukan yaitu dengan memenuhi 8 kriteria dari prinsip ekowisata yang belum terpenuhi.

\subsection{Saran}

Untuk pengelola ekowisata Desa Liang Ndara diharapkan agar bisa meningkatkan kembali upaya pengembangan yang telah dilakukan dan melakukan upaya yang belum dilakukan dengan menerapkan prinsip-prinsip ekowisata. Untuk pemerintah Kabupaten Manggarai Barat agar lebih memperhatikan pengembangan potensi ekowisata di Desa Liang Ndara dan untuk masyarakat agar lebih antusias lagi dalam mengikuti berbagai kegiatan terkait dengan pengembangan ekowisata sehingga dapat melestarikan dan mengembangkan potensi ekowisata untuk tetap berkelanjutan.

\section{DAFTAR PUSTAKA}

Arida, Nyoman Sukma. 2009. Meretas Jalan Ekowisata Bali.. Denpasar: Udayana University Press.

Arikunto, Suharsimi. 2013. Prosedur Penelitian Suatu Pendekatan Praktik. Jakarta: PT. Rineka Cipta.

Damanik, J. Dan Weber, H.F. 2006. Perencanaan Ekowisata Dari Teori ke Aplikasi. Yokyakarta: Andi Offest.

Pendit, Nyoman S. 1999. Wisata Konvensi, Potensi Gede Bisnis Besar. Jakarta: PT. Gramedia Pustaka.

Suryawan, Ida Bagus. 2014. Pengelolaan Potensi Ekowisata di Desa Cau Belayu, Kecamatan Marga Kabupaten Tabanan. Jurnal Analisis Pariwisata 14(1): 56-60. 